statehood have accumulated. The authorities, unwillingness to modernize the consolidating idea and the preservation of the old model of political governance are not able to resolve the problems that have arisen, especially in conditions when there are political forces in Poland interested in destabilizing the situation and changing the political regime in Belarus.

Keywords: Belarus, political technologies, consolidating idea, Lukashenko

РАХИМОВ Рамиль Насибуллович - кандидат исторических наук, доцент; заведующий кафедрой истории России, историографии и источниковедения Института истории и государственного управления Башкирского государственного университета (450076, Россия, г. Уфа, ул. Заки Валиди, д.32; rakhimovrn@mail.ru)

ЕФИМЕНКО Антон Дмитриевич - магистрант кафедры истории России, историографии и источниковедения Института истории и государственного управления Башкирского государственного университета (450076, Россия, г. Уфа, ул. Заки Валиди, д. 32; pajjkat97@таil.ru)

\title{
ЧТО ПОЗВОЛЕНО ЮПИТЕРУ... ОСОБЕННОСТИ НАЦИОНАЛЬНОЙ ПОЛИТИКИ В БАШКИРСКОЙ АССР В ГОДЫ ВЕЛИКОЙ ОТЕЧЕСТВЕННОЙ ВОЙНЫ
}

\begin{abstract}
Аннотация. В статье рассматриваются трансформации национальной политики в годы Великой Отечественной войны от интернационализма до русского национализма, а к концу войны - баланса в рамках «советского патриотизма». В ситуации национальных автономий партийные и творческие элиты не успевали отмечать новые акценты национальной политики, инерция патриотического воспитания опиралась на выработанный алгоритм и сложившийся пантеон национальных героев. Все это привело к разрыву представлений о содержании национальной политики между центром и периферией. Автор отмечает, что противоречия между гибкостью представлений в национальной политике руководства партии, и стандартность понимания ее на местах, привели к серьезному вмешательству центра в общественную жизнь автономных республик в 1944 - 1945 гг.
\end{abstract}

Ключевые слова: национальная политика, Башкирская АССР, Великая Отечественная война, патриотическое воспитание

B истории Великой Отечественной войны большой интерес вызывают аспекты, связанные с особенностями проведения национальной политики [Вдовин 2003; Синицын 2009; Брандербергер 2009]. Историки выделяют три этапа ее реализации. Первый (июнь 1941 - ноябрь 1942 гг.) отказ от проведения политики «интернационализма», усиление русского национального фактора. Второй (ноябрь 1942 - 1943 гг.) возврат к русским национальным традициям и великодержавию, как основам государственной политики. В заключительный период (1944 - май 1945 гг.) выравнивание возникшего ранее крена в сторону усиления русского национального патриотизма. Политика «советского патриотизма» позиционировала СССР как «великую державу» всех народов, хотя во главе с русским народом. Советская национальная политика в Великой Отечественной войне показала высокую эффективность, проявив маневренность, гибкость и способность к манипулированию национально-патриотическими чувствами [Синицын 2009: 26].

На региональном уровне обращение к работам, посвященным данной теме создает впечатление о неизменности дискурса советской историографии 
[Шпинева 2004]. Либо предлагается теория уничтожения татарского народа, через его депортацию [Кабирова 2013: 397 - 398]. «Духовное порабощение и уничтожение истории» татарского народа было реализовано постановлением партии в 1944 г. [Галлямова 2013: 407]. Башкирская историография рассматривает идентичную реакцию центра как акт произвола, либо констатирует, что «верх взяли тенденции жесткой централизации и унификации» [Ахмадиев 2011: 83-84; Сулейманова 2011: 77].

В данной статье ставится задача объяснить объективно сложившиеся причины столь резкой реакции центра на национальную политику, проводимую в автономных республиках, на примере Башкирской АССР.

В начале войны, в отношении идеологии республиканское руководство оказалось близоруким, своевременно не заметив резкую смену риторики центра, оставаясь на прежних позициях интернационализма. 22 августа 1941 г. бюро Башкирского обкома ВКП (б) приняло предложение Союза советских писателей Башкирии об издании литературного антифашистского сборника на башкирском языке ${ }^{1}$. В реальной жизни тысячи мужчин отправлялись на фронт, в республику шли эшелоны с заводским оборудованием и людьми. Критическая ситуация на фронте привела к тому, что 13 ноября ГКО принял постановление, предполагавшее формирование национальных соединений. В БАССР были сформированы 112-я и 113-я башкирские кавалерийские дивизии. Командование столкнулось с тем, что большинство воинов, не владело русским языком ${ }^{2}$.

Патриотическое воспитание перестраивалось с учетом новых реалий медленно. Оно шло по линии издания брошюр, публикации газетных очерков, театральных постановок. Башкирский академический театр включил в репертуар 1943 - 1944 гг. пьесу Б. Бикбая «Кахым-туря» об участии башкир в войне против Наполеона и М. Бурангулова «Идукай и Мурадым» о борьбе с монголами. В национальной республике вставал вопрос о собственных национальных героях-патриотах. Из Башкирии на войну с Наполеоном ушло 20 башкирских полков, память об этом сохранилась в фольклоре. Отечественная война 1812 г. сразу стала темой близкой и понятной [Раимов 1943].

Салават Юлаев как герой, связывавший башкирский народ с русским, был назван секретарем ЦК ВКП (б) А.А. Ждановым в 1937 г. на пленуме Башкирского обкома ВКП (б) ${ }^{3}$. В следующем году обком обратился в Москву с просьбой снять кинофильм о Салавате Юлаеве. Фильм Я. Протазанова «Салават Юлаев», снятый по роману С.П. Злобина вышел на экраны 21 февраля 1941 г. Имя Салавата стало известно всей стране. Не случайно его образ использовался в политической работе в башкирской кавалерийской дивизии 4 .

Поскольку в это время профессиональных историков в республике не было, то Башкирский научно-исследовательский институт языка и литературы им. М. Гафури сосредоточился на исследованиях в области языка и фольклора. Вполне понятно, что фольклористы обратились к героям средневековья. Фольклорист Бурангулов опубликовал в Уфе в 1942-1943 гг. сборники «Отечественная война», «Эпос о батырах» [Хусаинова 2011: 98]. Записанный

1 Документы и материалы по истории башкирского народа (1941-1985) / Сост. Р.Н. Сулейманова и др. Уфа, 2012. С. 256.

2 Региональные особенности национальной политики СССР в годы Великой Отечественной войны 1941-1945 гг. Башкирская АССР: Сборник документов и материалов / отв. ред. Р.Н. Сулейманова. Уфа, 2011. С. 28.

3 Национальный архив Республики Башкортостан (далее - НА РБ). Ф. П-122. Оп. 17. Д. 54 А. Л. 88 .

4 Документы и материалы по истории башкирского народа... С. 83. 
и опубликованный им эпос «Идукай и Мурадым», активно использовался в патриотической работе. В большей степени этнографическая пьеса «Башкирская свадьба» также шла с успехом в театре.

Не различая вымысел, народную фантазию и реальность, публикаторы в патриотической риторике выдавали действия фольклорных героев как историю. Это хорошо заметно по «Письму башкирского народа башкирским джигитам-фронтовикам» от 23 августа 1943 г. Обращаясь к воинам - «потомкам Салават-батыра», авторы напоминают про завет батыров эпоса «Идукай и Мурадым» - борцов за свободу башкирского народа ${ }^{1}$. В итоге фольклор стал самой историей. Утверждалось, что «башкирские конники во главе с КахимТуря, Ян-Туря и Абдрахманом Акъегитовым одними из первых вошли в Париж» 2 .

В 1943 г. стратегическая инициатива перешла в руки советского командования. Необходимость в национальных соединениях отпала, а выросший в 1941 - 1943 гг. национализм вызывал опасения. В 1944 г. армия перешла границу, началось освобождение Европы. Вставали перспективы создания социалистических стран в Восточной Европе.

К этому времени наметился раскол между историками, стоявшими на позициях русского великодержавного национализма и ортодоксальными коммунистами-интернационалистами. В мае - июле 1944 г. ЦК ВКП (б) провело совещание историков с целью разобраться в конфликте, но единого решения выработано не было. На совещании подверглись критике как сторонники «великодержавного шовинизма», так и «очернители героического прошлого русского народа». В отношении национальных республик была предложена модель добровольного вхождения народов в состав Российской империи. С лета 1944 г. власть выступила как против «очернения прошлого», так и против возвеличивания дореволюционного прошлого.

Изменение оценок истории народов СССР центром привело к ревизии национальной политики проводимой в автономных республиках. Она шла с обвинительным уклоном. 9 августа 1944 г. ЦК ВКП (б) принял постановление «О состоянии и мерах улучшения массово-политической и идеологической работы в Татарской партийной организации» ${ }^{3}$. Основное обвинение шло по линии национальной политики (приукрашивание Золотой Орды, популяризация ханско-феодального эпоса об Идегее).

Началась проверка в Башкирии. 17 октября постановление бюро обкома ВКП (б) «О состоянии и мерах улучшения массово-политической и пропагандистской работы в республике» признало, что пропагандистская работа находится в запущенном состоянии. В декабре 1944 г. из Москвы прибыли Н. Чертова и Р. Фаизова в составе комиссии президиума Союза писателей СССР. Была создана секретная комиссия, материалы которой легли в основу докладной записки Н.С. Тихонова в ЦК ВКП (б) [Сулейманова 2011: 76]. 22 декабря на собрании областного партийного актива с докладом о недостатках и задачах идеологической и массово-политической работы выступил первый секретарь С.Д. Игнатьев. Под удар попал Бурангулов с пьесами «Идукай и Мурадым» и «Башкирская свадьба», где «роскошная жизнь баев и тарханов, не знающих ни в чем нужды» выдавалась за жизненный уклад всего башкирского народа ${ }^{4}$. А ведь еще в 1937 г. Жданов, выступая на пленуме Башкирского обкома, обличал

1 Региональные особенности национальной политики СССР... С. 49.

2 Региональные особенности национальной политики СССР... С. 51.

3 Коммунистическая партия Советского Союза в резолюциях и решениях съездов, конференций и пленумов ЦК (1898-1986).М., 1985. Т. 7: 1938-1945. С. 513-520.

4 Региональные особенности национальной политики СССР... С. 279-281. 
местных националистов следующими примерами: «На сцене башкирского теа-


обрушился на Бикбая за пьесу «Кахым Туря» и публикатора Карамзина за сказку «Кахым Туря», в ней Москву от Наполеона освободили башкиры. Более того, было написано, что башкиры разорили Париж и взяли в плен Наполеона, а русские генералы, чтобы не мешать брать Париж, «отошли в сторону» ${ }^{2}$. В речах партийной элиты критике подвергались те самые образы, что самим же обкомом использовались в «Письме башкирского народа» - Идукай и Мурадым, Кахым-туря. В начале 1945 г. работники ЦК ВКП (б) отправили докладную записку Маленкову «Об извращениях и ошибках в идеологической работе Башкирского обкома партии». Итогом стало принятое 27 января 1945 г. постановление ЦК ВКП (б) «О состоянии и мерах улучшения агитационно-пропагандистской работы в Башкирской партийной организации». В нем отмечались недостатки в работе партийных организаций Башкирской АССР. Так в «Очерках по истории Башкирии», в литературных произведениях «Идукай и Мурадым», «Эпос о богатырях» не проводилось разграничения между национально-освободительными движениями башкирского народа и набегами башкирских феодалов, идеализировалось патриархально-феодальное прошлое. В пьесе «Кахым-Туря» «противопоставляются друг другу русские и башкирские воины» ${ }^{3}$.

Что же произошло? По мнению И.В. Кучумова явления, приведшие к вмешательству центра, были проявлением «идеализации прошлого своих народов, настороженного отношения к русской культуре, склонности к культурному самоизоляционизму, игнорирования многонационального характера региона» ${ }^{4}$. Бранденбергер считает, что «как только крайняя необходимость 1941 - 1943 годов стала ослабевать, партийная идеология вернулась к бескомпромиссной версии оформившейся после 1937 года линии: этническое превосходство русского народа в советском обществе» [Брандербергер 2009: 156].

Мы считаем, что события конца 1944 - начала 1945 гг. в БАССР, как и ранее в ТАССР - следствие несоответствия национальной политики проводимой местными властями политике проводимой руководством партии. Но связано это было не с линией великодержавного национализма, складывающегося до войны. Партийное руководство удачно использовало ленинский подход - временного отказа от стратегической линии для решения текущего момента. На местах не успели заметить этого.

Обрашение к идеям русского национализма, великодержавия, для Сталина было тактическим приемом. Как только опасность для страны исчезла, изменился геополитический расклад, он вернулся к довоенным подходам, правда теперь «советский патриотизм» получил «русскую» основу. Эти стремительные изменения риторики не смогли увидеть ученые-историки, находившиеся в Москве, что вскрыл 1944 г. Казусом было то, что партийное руководство проглядело факт появления непримиримых группировок. Этого не смог уловить и И.Г. Эренбург, призывавший мстить немцам.

Партийные организации национальных республик не успевали отследить смену курса. С одной стороны от них требовалась ежедневная патриотическая

${ }^{1}$ НА РБ. Ф. П-122. Оп. 17. Д. 54А. Л. 83.

2 Региональные особенности национальной политики СССР... С. 279 - 281.

3 Коммунистическая партия Советского Союза в резолюциях... Т. 7. С. 540.

4 Кучумов И.В. Влияние эвакуации населения из западных областей СССР на социально-экономические процессы в Башкирии в годы Великой Отечественной войны - Genesis: исторические исследования. 2018. № 10. Доступ: https://nbpublish.com/library_read_article. php?id=27448 (проверено 07.12.2020). 
работа, с другой стороны для башкирского и татарского населения не имели наполнения имена Александра Невского и Дмитрия Донского, Суворова и Кутузова. Гражданская история начала преподаваться только после 1934 г., имелись языковые трудности, часть интеллигенции была репрессирована, часть ушла на фронт, а оставшиеся творческие работники на свой страх и риск, на основе того, что знали и как понимали происходившие события, создавали героев, зовущих на подвиг. Поэтому они продолжали тиражировать те образы и имена, что интуитивно были «нащупаны» в тяжелые месяцы 1941 - 1942 гг. Кто-то, благодаря кино, получил всесоюзную известность, кто-то был известен только башкирскому населению. Главное, что все это было созвучно тем людям, на которых были ориентированы произведения. Все это, в том числе принесло Победу. Но партийное руководство уже строило новый, послевоенный мир и готовилось к нему идеологически. Национальная история автономий с героями средневековья в него не вписывалась.

Статья публикуется при поддержке Школы молодого этнополитолога в Республике Башкортостан (грант Фонда президентских грантов 19-2-022447).

\section{Список литературы}

Ахмадиев Р.Б. 2011. Литература и драматургия - История башкирского народа: в 7 томах. T. VI. М.: Восточная литература, С. 78-85.

Бранденбергер Д. 2009. Национал-больщевизм. Сталинская массовая культура и формирование русского национального самосознания (1931-1956). СПб.: ДНК, $415 \mathrm{c}$.

Вдовин А.И. 2003. Национальный вопрос и национальная политика в СССР в годы Великой Отечественной войны: мифы и реалии - Вестник Московского университета. Серия 8. История. № 5. С. $24-54$.

Галлямова А.Г. 2013. Национальный вопрос и политическая ситуация в Татарской АССР в середине 1940-х - первой половине 1980-х г2. - История татар с древнейших времен: в 7 томах. Т. VII. Казань. С. $407-424$.

Кабирова А.Ш. 2013. Татарская АССР - важная тыловая база СССР-История татар с древнейших времен: в 7 томах. Т. VII. Казань. С. 388 - 399.

Кучумов И.В. 2018. Влияние эвакуации населения из западных областей СССР на социально-экономические процессы в Башкирии в годы Великой Отечественной войны - Genesis: исторические исследования. № 10. C. 83 - 93.

Раимов Р.М. 1943. Башкирский народ в Отечественной войне 1812 года. Уфа: Башгосиздат, 16 с.

Синицын Ф.Л. 2009. Национальная политика СССР в Великой Отечественной войне (1941-1945). Автореф. дис....канд. ист. наук. М. 29 с.

Сулейманова Р.Н. 2011. Участие башкир в общественно-политической жизни - История башкирского народа: в 7 томах. T. VI. М.: Восточная литература. C. $68-77$.

Хусаинова Г.Р. 2011. Сбор, издание башкирского фольклора - История башкирского народа: в 7 томах. T. VI. М.: Восточная литература. С. 97 - 103.

Шпинева Ю.И. 2004. Осуществление национальной государственной политики на Южном Урале в годы Великой Отечественной войны (1941-1945 гг.). Автореф. дисс...канд.ист.наук. Оренбург. 28 с. 
RAKHIMOV Ramil> Nasibullovich, Cand.Sci. (Hist.), Associate Professor; Head of the Department of Russian History, Historiography and Source Study, Institute of History and Public Administration, Bashkir State University (32 Zaki Validi St., Ufa, 450076, Russia; rakhimovrn@mail.ru)

YEFIMENKO Anton Dmitriyevich, Master's student of the Department of Russian History, Historiography and Source Studies, Institute of History and Public Administration, Bashkir State University (32 Zaki Validi St., Ufa, 450076, Russia; pajjkat97@mail.ru)

\title{
WHAT IS ALLOWED TO JUPITER ... FEATURES OF THE NATIONAL POLICY IN THE BASHKIR ASSR DURING THE GREAT PATRIOTIC WAR
}

\begin{abstract}
The article examines the transformation of national policy during the Great Patriotic War from internationalism to Russian nationalism, and by the end of the war - the balance within the framework of «Soviet patriotism. «In the situation of national autonomies, the party and creative elites did not have time to note new accents of national policy, the inertia of patriotic education was based on the developed algorithm and the established pantheon of national heroes. All this led to a break in ideas about the content of national policy between the center and the periphery. The author notes that the contradictions between the flexibility of ideas in the national policy of the party leadership, and the standard understanding of it at the local level, led to serious interference by the center in the social life of the autonomous republics in 1944-1945. Keywords: national policy, Bashkir ASSR, Great Patriotic War, patriotic education
\end{abstract}

ЦИБЕНКО Вероника Витальевна - кандидат исторических наук, директор Центра междисциплинарных гуманитарных исследований, Южный федеральный университет (344006, Россия, г. Ростовна-Дону, ул. Большая Садовая 105; tsibenkovv@sfedu.ru)

ТЛОСТНАКОВ Аскер Асланович - кандидат политических наук, старший научный сотрудник Центра междисииплинарных гуманитарных исследований, Южный федеральный университет (344006, Россия, г. Ростов-на-Дону, ул. Большая Садовая 105; tlostnakov@sfedu.ru)

\section{РЕПАТРИАЦИЯ ЧЕРКЕСОВ КАК РЕСУРС ПОЛИТИЧЕСКОЙ МОБИЛИЗАЦИИ: ТРАНСНАЦИОНАЛЬНЫЙ ПОДХОД}

\begin{abstract}
Аннотация. Статья посвящена репатриации черкесов, рассматриваемой как ресурс черкесского нациестроительства. Авторы анализируют один из новейших подходов к репатриации, определяющий ее как транснациональное явление. Через погружение в историю «черкесской репатриации» и анализ основных акторов этого процесса авторами определены предпосылки для формирования транснационального подхода к репатриации, раскрыты его сущностные характеристики и ключевые акторы.
\end{abstract}

Ключевые слова: черкесы, Кавказ, репатриация, диаспора, нациестроительство, транснациональная модель репатриации

Термин «репатриация» (от лат. repatrio, «возвращаться на родину») широко распространен в научной и правовой сферах в применении к людям, ценностям искусства и даже финансовым капиталам. В отношении диаспоры репатриация понимается как добровольное возвращение в страну происхождения или на историческую родину первого и последующих поколений, и также 